\title{
Protein and Glycoprotein Synthesis and Secretion by the Diabetic Liver
}

\author{
E. M. Berry, E. Ziv, and H. Bar-On \\ Lipid Research Laboratory, Department of Medicine B, Hadassah University Hospital, Jerusalem, Israel
}

\begin{abstract}
Summary. Protein and glycoprotein synthesis and secretion by isolated perfused livers and isolated hepatocytes from control and streptozotocin diabetic rats have been investigated. ${ }^{3} \mathrm{H}$-Leucine and ${ }^{14} \mathrm{C}$ glucosamine incorporation were used as markers for protein and glycoprotein synthesis and secretion. Total protein secretion was reduced by $50 \%$ in the perfusate $(\mathrm{p}<0.001)$ and by $36 \%$ in hepatocytes $(\mathrm{p}$ $<0.05$ ), but glycoprotein secretion was unchanged in both preparations from diabetic animals. These differences were not due to changes in the available pool sizes of the different labels. On liver fractionation, all membrane components from the liver of diabetic animals had lowered ${ }^{3} \mathrm{H}$-leucine: ${ }^{14} \mathrm{C}$ glucosamine ratios in relation to the control animals. This was caused by enhanced glucosamine incorporation in relation to that of leucine. It is suggested that whereas protein synthesis is decreased in acutely diabetic rats, the production of glycoproteins is normal and occurs by the same pathway as in control animals.
\end{abstract}

Key words: Streptozotocin diabetes, glycoprotein synthesis, glycoprotein secretion, protein synthesis, liver perfusion, isolated hepatocytes, leucine pool size, glucosamine pool size.

Glycoproteins exist as both secretory and structural components in the liver cell. The protein backbone is synthesized on membrane-bound ribosomes and glycosidation takes place on the rough membranes, smooth membranes and in the Golgi apparatus by glucosyltransferase enzymes [1]. In diabetes mellitus the capillary basement membrane is thickened probably due to the deposition of material largely com- posed of glycoprotein. Spiro has shown that in the kidney of diabetic rats there is an increase in glucosyltransferase activity $[2,3]$. He suggests that there is a preferential channelling of glucose into metabolic pathways independent of insulin activity. Information concerning the liver is of special interest since this organ is responsible for the synthesis of the majority of the plasma glycoproteins [4]. Glycoprotein synthesis by the isolated perfused liver and hepatocytes serves as a model of both secretion [5] and incorporation into subcellular membranes. In this paper, using such systems, we compare the synthesis of proteins and glycoproteins by livers from control and diabetic animals.

\section{Materials and Methods}

\section{Animals and Diet}

Male rats of the Hebrew University strain, weighing $250-300 \mathrm{~g}$ were fed a semi-purified sucrose-rich diet consisting of $20 \%$ vitamin-free casein, $60 \%$ sucrose, $5 \%$ lard, $1 \%$ vitamin mixture, $4 \%$ salt mixture and $10 \%$ cellulose [6]. The rats were fed this diet for three weeks prior to induction of diabetes. Streptozotocin $(40 \mathrm{mg} /$ $\mathrm{kg}$ body weight) was injected into the tail vein, as previously described [7]. Experiments were performed on fed rats 2-4 days after the streptozotocin injection. In all the diabetic animals blood glucose concentration was over $350 \mathrm{mg} / \mathrm{dl}$.

\section{Liver Perfusion}

Isolated liver perfusion was performed as described by Mortimore et al. [8]. The perfusate consisted of Krebs-Ringer bicarbonate solution, $\mathrm{pH} 7.4$, containing glucose $4 \mathrm{~g} / 1$, streptomycin $0.1 \mathrm{~g} / \mathrm{l}$, penicillin $1000000 \mathrm{U} / 1,30 \mathrm{~g} / \mathrm{l}$ bovine serum albumin, a mixture of the naturally occurring aminoacids (excluding leucine) $0.1 \mathrm{mmol} / 1$ of each, and heparin $1000 \mathrm{U} / \mathrm{l}$. Human red blood cells, washed twice with $0.154 \mathrm{~mol} / 1$ saline, were added to the perfusate to achieve a haematocrit of approximately $20 \%$. The liver was washed first with $40 \mathrm{ml}$ Krebs-Ringer bicarbonate solution. It was then perfused in a recycling system with a volume of $60-70 \mathrm{ml}$. 
Throughout the perfusion, sodium palmitate complexed to serum albumin ( $4: 1$ molar ratio) was infused into the portal vein at a rate of $0.2 \mathrm{mmol} / \mathrm{h}$, using a constant perfusion pump [9]. Oxygenation with $95 \% \mathrm{O}_{2}, 5 \% \mathrm{CO}_{2}$, was carried out as described by Hamilton et al. [10] using silastic tubing (Dow-Corning, Michigan). At zero time, $50 \mu \mathrm{Ci}$ of ${ }^{3} \mathrm{H}$-leucine and $10 \mu \mathrm{Ci}$ of ${ }^{14} \mathrm{C}$-glucosamine were added to the perfusate immediately after the wash. Samples of the perfusate were taken for the determination of the leucine and glucosamine incorporation into proteins at zero time, and every 30 min thereafter for $3 \mathrm{~h}$.

\section{Preparation of the Subcellular Fractions}

In order to isolate the labelled subcellular-organelle membranes, fractionation of the perfused livers was performed $3 \mathrm{~h}$ after the addition of the radioactive markers [4]. At this time the liver was removed, weighed and homogenized. The Golgi apparatusenriched fraction was isolated according to Morre and co-workers [11]. The purity of this fraction was verified by electron microscopy and marker enzyme determination. Enzyme activity of UDP-galactose ovalbumin galactosyltransferase was measured in all the subcellular fractions by the method of Hodson and Brenchley [12] and was found principally in the Golgi apparatus enriched fraction. The activity was concentrated seventy-fold in this fraction when compared to the other membrane fractions. Mitochondria were prepared from the $2000 \times \mathrm{g}$ supernatant according to Sottocasa et al. [13]. Smooth membranes, rough membranes, polysomes and post-microsomal supernatant fractions were prepared according to Sunshine et al. [14] except that the $\mathrm{MgCl}_{2}$ concentration of the gradient buffers was increased from 5 to $10 \mathrm{mmol} / 1$ (Dice and Schimke [15]). Protein radioactivity of the erythrocyte free perfusate, hepatocytes and liver fractions was determined by the method of Mans and Novelli [6]. $100 \mu \mathrm{l}$ samples were placed on labelled filter papers (Whatman 3MM) allowed to dry for a few minutes and then dropped in $5 \%$ TCA solution $(5 \mathrm{ml} /$ paper) at $4{ }^{\circ} \mathrm{C}$. After all the samples had been taken, the filter papers were washed successively in $5 \% \mathrm{TCA}$ at $50^{\circ} \mathrm{C}$, cold TCA, ethanol and ether $(1: 1 \mathrm{v} / \mathrm{v})$ and finally ether. The papers were dried in air and then transferred to counting vials containing $10 \mathrm{ml}$ scintillation fluid (Toluene: PPO:POPOP). The radioactivity was measured in a liquid scintillation counter (Packard Instrument Co., model 3380 ).

\section{Hepatocyte Preparation}

Hepatocytes were prepared according to the method of Zahlten and Stratman [17] using collagenase. Incubations were made in 5.0 $\times 2.5 \mathrm{~cm}$ glass scintillation vials over a period of $2 \mathrm{~h}$. The reaction mixture, in a total volume of $1.0 \mathrm{ml}$, was based on calcium-free Krebs-Henseleit buffer [18] with gelatin. The mixture contained $2-3 \times 10^{6}$ cells; $\mathrm{NaCl} 118.6 \mu \mathrm{mol} ; \mathrm{KCl} 1.19 \mu \mathrm{mol} ; \mathrm{KH}_{2} \mathrm{PO}_{4}$ $1.19 \mu \mathrm{mol} ; \mathrm{MgSO}_{4} 1.1 \mu \mathrm{mol} ; \mathrm{NaHCO}_{3} 24.5 \mu \mathrm{mol} ;$ gelatin $15 \mathrm{mg}$; L-4,5- ${ }^{3} \mathrm{H}$-leucine $0.02 \mu \mathrm{mol}(5.0 \mu \mathrm{Ci}) ; \mathrm{D}-1-{ }^{14} \mathrm{C}$-glucosamine $0.0068 \mu \mathrm{mol}(0.35 \mu \mathrm{Ci})$. The calcium ion concentration of the incubation medium was derived from the gelatin and ranged between $0.5-0.7 \mathrm{mmol} / 1$ [19]. The vials were gassed continuously with $95 \% \mathrm{O}_{2}$ and $5 \% \mathrm{CO}_{2}$ in a shaking water bath at $37^{\circ}$ without any preincubation. Aliquots were taken at timed intervals from the total incubation mixture, cells and supernatant (after centrifugation). The integrity of the hepatocytes was confirmed by their ability to perform gluconeogenesis from dihydroxyacetone and from their response to glucagon. Viability was assessed by trypan blue exclusion which was observed consistently in $85-95 \%$ of the cells. Conversion from the number of hepatocytes to $\mathrm{g}$ wet liver weight was calculated according to the method of Zahlten and Stratman [17].

\section{Determination of Pool Sizes of Leucine and Glucosamine}

The validity of the incorporation results depends on the available pool sizes of leucine and glucosamine in diabetic and non-diabetic rats. These were derived from the method of de Fernandez Sese and Scornik [20], assuming a rapid equilibration between the extracellular and intracellular concentrations of these precursors [21]. Known concentrations of leucine and glucosamine were added to the hepatocytes and the rates of their incorporation into TCA precipitable material were measured. It was then possible to calculate the dilution factors (which approximate to the "available pool sizes") by the standard isotope dilution equation $[22,23]$.

$y=(x+d)\left(\frac{C_{o}}{C}-1\right)$

where: $y=$ the quantity of non-labelled leucine or glucosamine added (known);

$\mathrm{x}=$ the quantity of radioactive label added (known);

$\mathrm{d}=$ the amount of non-labelled leucine or glucosamine present intracellularly which dilutes the added label (= the dilution factor);

$\mathrm{C}_{\mathrm{o}}=$ the count rate of the TCA precipitate in the medium when only the radioactive label is added, $\mathrm{cpm} / \mathrm{min}$ (known);

$\mathrm{C}=$ the count rate of the TCA precipitate in the medium after the addition of non-labelled leucine or glucosamine to an identical reaction mixture, $\mathrm{cpm} / \mathrm{min}$ (known).

By changing the amount of (y), different count rates (C) were measured, and then a graph was plotted of $(y)$ against $\left(\frac{C_{0}}{C}-1\right)$. The gradient is equal to $(x+d)$.

In each experiment the amount of only one label substrate was altered. There was no change in the incorporation of one label in the presence of varying concentrations of the other (leucine or glucosamine) (not shown).

The dilution factors (d) were derived from the gradients, and the available pool sizes were calculated from the initial concentrations of leucine and glucosamine of $20 \mathrm{mmol} / 1$ and $6.8 \mathrm{mmol} / \mathrm{l}$ respectively. There was no difference in the dilution factor for leucine between diabetic and non-diabetic rats.

The available pool size of leucine in both diabetic and nondiabetic rats was found to be between 80 and $90 \mathrm{mmol} / 1$. The glucosamine pool in the diabetic animals was $3.7 \mathrm{mmol} / 1$ as compared to $1.4 \mathrm{mmol} / 1$ in the non-diabetic animals. These results were calculated from three diabetic and three non-diabetic preparations.

$\mathrm{L}-4,5-{ }^{3} \mathrm{H}$-leucine $60.0 \mathrm{Ci} / \mathrm{mmol}$ and $\mathrm{D}-1-{ }^{14} \mathrm{C}$-glucosamine $59.0 \mathrm{mCi} / \mathrm{mmol}$ were purchased from the Radiochemical Centre, Amersham, England. Streptozotocin was kindly supplied by Dr. W. Dulin of Upjohn Co., Kalamazoo, Mich., USA. Bovine serum albumin (Fraction V powder, essentially fatty acid free) was purchased from Sigma, St. Louis, U.S.A. Collagenase (CLS II) was supplied by Worthington Biochemical Corporation, New Jersey, U.S.A. Aminoacids were obtained from Nutritional Biochemical Corporation, Cleveland, Ohio, U.S.A.

The Student $t$-test (two-tailed) was used to evaluate the significance of differences between the means in the groups studied. All results are expressed as mean \pm SEM.

\section{Results}

The synthesis and secretion of total proteins and glycoproteins by livers from diabetic and control ani- 

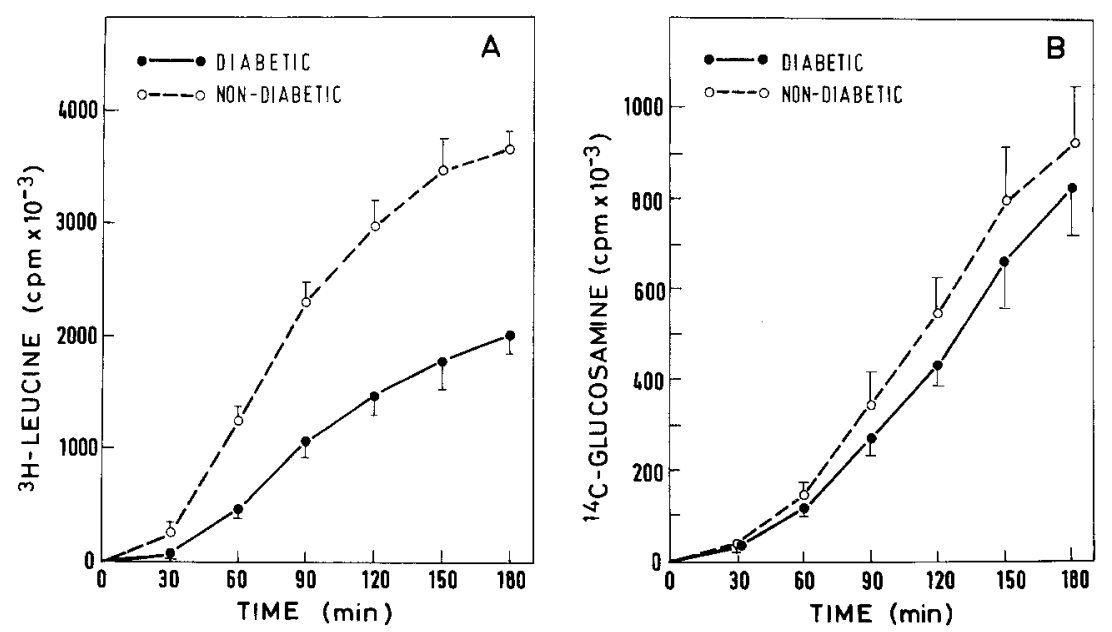

Fig. $1 \mathrm{~A}$ and $\mathbf{B}$. The incorporation of ${ }^{3} \mathrm{H}$ leucine and ${ }^{14} \mathrm{C}$-glucosamine into secreted proteins in isolated perfused livers from diabetic and nondiabetic rats (mean of at least 4 experiments). Results given as $\mathrm{cpm} / \mathrm{g}$ wet wt liver (mean \pm SEM). A The incorporation of ${ }^{3} \mathrm{H}$ leucine into TCA precipitate; $\mathbf{B}$ The incorporation of ${ }^{14} \mathrm{C}$-glucosamine into TCA precipitate

Table 2. Rate of incorporation of ${ }^{3} \mathrm{H}$-leucine and ${ }^{14} \mathrm{C}$-glucosamine into TCA precipitate in secreted and cellular proteins from isolated hepatocytes. Results given as $\mathrm{cpm} \times 10^{-3} / \mathrm{min} / \mathrm{g}$ liver

\begin{tabular}{|c|c|c|c|c|c|c|}
\hline & \multicolumn{3}{|l|}{ Cells } & \multicolumn{3}{|c|}{ Secreted proteins } \\
\hline & ${ }^{3} \mathrm{H}$-leucine & $\begin{array}{l}{ }^{14} \mathrm{C}- \\
\text { glucosamine }\end{array}$ & $\begin{array}{l}\text { Ratio } \\
{ }^{3} \mathrm{H} \text {-leucine }\end{array}$ & ${ }^{3} \mathrm{H}$-leucine & $\begin{array}{l}{ }^{14} \mathrm{C}- \\
\text { glucosamine }\end{array}$ & $\begin{array}{l}\text { Ratio } \\
{ }^{3} \mathrm{H} \text {-leucine }\end{array}$ \\
\hline & & & $\overline{{ }^{14} \mathrm{C} \text {-glucosamine }}$ & & & ${ }^{14} \mathrm{C}$-glucosamine \\
\hline Diabetic & $26.0 \pm 3.2$ & $11.1 \pm 1.9$ & 2.3 & $17.9 \pm 2.5$ & $11.6 \pm 1.2$ & 1.5 \\
\hline Non-diabetic & $29.5 \pm 4.0$ & $8.1 \pm 1.8$ & 3.6 & $27.8 \pm 3.0$ & $12.2 \pm 2.7$ & 2.3 \\
\hline $\mathrm{P}$ & NS & NS & & $<0.05$ & NS & \\
\hline
\end{tabular}

Each value represents the mean \pm SEM of $4-6$ experiments

$\mathrm{NS}=$ not significant

Table 1. Rate of incorporation of ${ }^{3} \mathrm{H}$-leucine and ${ }^{14} \mathrm{C}$-glucosamine into TCA precipitate in the perfusate from isolated liver perfusions. Results given as $\mathrm{cpm} \times 10^{-3} / \mathrm{min} / \mathrm{g}$ liver

\begin{tabular}{llll}
\hline & ${ }^{3} \mathrm{H}$-leucine & $\begin{array}{l}{ }^{14} \mathrm{C} \text { - } \\
\text { glucosamine }\end{array}$ & $\begin{array}{l}\text { Ratio } \\
{ }^{3} \mathrm{H} \text {-leucine } \\
{ }^{14} \mathrm{C} \text {-glucosamine }\end{array}$ \\
\hline Diabetic & $16.7 \pm 0.3$ & $6.2 \pm 0.5$ & 2.8 \\
Non-diabetic & $33.3 \pm 0.4$ & $7.2 \pm 0.5$ & 4.6 \\
$\mathrm{P}$ & $<0.001$ & NS & \\
\hline
\end{tabular}

Each value represents the mean \pm SEM of $4-6$ experiments $\mathrm{NS}=$ not significant

mals were compared. The secretion of proteins into the perfusate, as measured by the incorporation of ${ }^{3} \mathrm{H}$-leucine into TCA precipitable material is shown in Figure $1 \mathrm{~A}$. There was a lag period of $15-30 \mathrm{~min}$ which preceded the secretion of proteins into the perfusate in both preparations but the rate of protein secretion by the diabetic liver was markedly decreased. Figure 1B shows that, in contrast to total protein secretion, glycoprotein production, as meas- ured by ${ }^{14} \mathrm{C}$-glucosamine incorporation into $\mathrm{TCA}$ precipitate from the perfusate, was not significantly altered in the diabetic rat livers. The rates of incorporation of the radioactive labels are given in Table 1. The lowered ${ }^{3} \mathrm{H}$-leucine: ${ }^{14} \mathrm{C}$-glucosamine ratio in the diabetic preparations is due principally to the decrease in incorporation of leucine by $50 \%$.

In the isolated hepatocytes the synthesis of proteins and glycoproteins was found to be linear over an incubation period of $120 \mathrm{~min}$. However there was also a latent period of approximately $30 \mathrm{~min}$ before secretion of labelled materials could be demonstrated in the medium. The rate of incorporation of ${ }^{3} \mathrm{H}$ leucine and ${ }^{14} \mathrm{C}$-glucosamine was measured both in the medium (secreted proteins) and in the cells (Table 2). The rate for each label was calculated during the linear incorporation period as the TCA precipitable cpm per unit time.

Considering secreted proteins from the hepatocytes there was a decrease in ${ }^{3} \mathrm{H}$-leucine incorporation in the diabetic animals by $36 \%$ whereas the incorporation rate of ${ }^{14} \mathrm{C}$-glucosamine was unaf- 


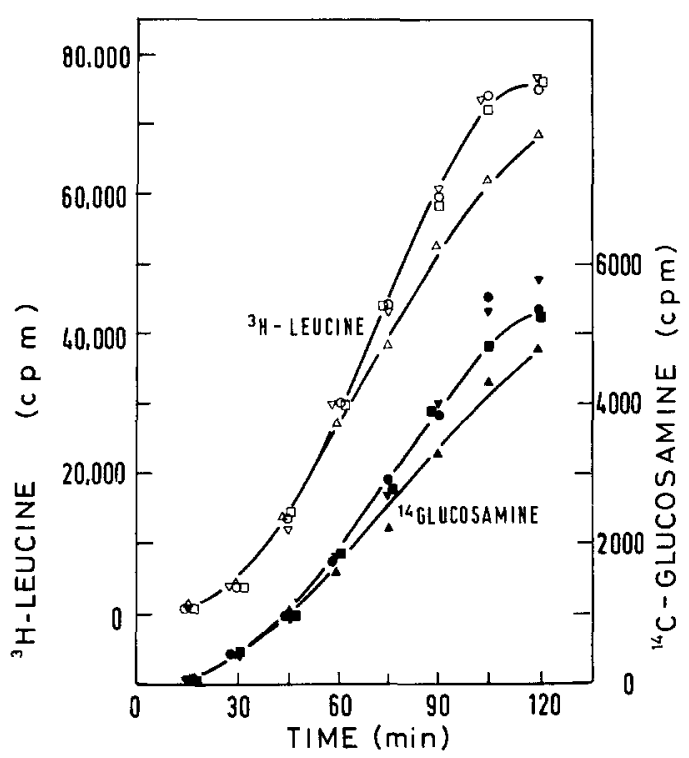

Fig. 2. ${ }^{3} \mathrm{H}$-leucine and ${ }^{14} \mathrm{C}$-glucosamine incorporation rate into secreted proteins in the presence of increasing concentrations of glucose in the medium of hepatocyte preparations obtained from non-diabetic rats. $0 \mathrm{mmol} / \mathrm{l}$ glucose; $\nabla \longrightarrow \nabla 1 \mathrm{mmol} / \mathrm{l}$ glucose; $\square 10 \mathrm{mmol} / \mathrm{l}$ glucose; $\mathbf{\Delta}-\mathbf{\Delta} 20 \mathrm{mmol} / \mathrm{l}$ glucose

fected. However, in the cellular proteins from the hepatocytes there were similar incorporation rates for the two labels.

The effect of different glucose concentrations in the medium on the incorporation of glucosamine into proteins is shown in Figure 2. Neither the incorporation of ${ }^{14} \mathrm{C}$-glucosamine nor ${ }^{3} \mathrm{H}$-leucine was altered by the addition to the incubation mixture of glucose in concentrations up to $10 \mathrm{mmol} / \mathrm{l}$. At $20 \mathrm{mmol} / 1$ there was a slight decrease in incorporation. The incorporation of ${ }^{14} \mathrm{C}$-glucosamine relative to ${ }^{3} \mathrm{H}$ leucine in both the supernatant and cells was unaffected by glucose concentration. In other words, there was no isotopic dilution of glucosamine by the concentrations of intracellular glucose found in the standard incubations. These varied between 1.0 and $3.0 \mathrm{mmol} / \mathrm{l}$.

Liver fractionation was performed to compare the incorporation of radioactive labels into the membrane-bound proteins of the liver (Table 3 ). With the exception of the homogenate and the post microsomal supernatant, the incorporation of ${ }^{14} \mathrm{C}$-glucosamine in the separate membrane fractions was higher in the diabetic preparations. However, the relative distribution of glycoproteins among the different subcellular fractions was similar in the diabetic and control livers. In both groups the highest ${ }^{3} \mathrm{H}$-leucine: ${ }^{14} \mathrm{C}$-glucosamine incorporation ratio was found in the post-microsomal supernatant and the lowest in the Golgi apparatus-enriched fraction.

\section{Discussion}

Reports of enhanced glycoprotein production in diabetes [24] correlate with the pronounced capillary basement membrane thickening characteristic of this disease. As this latter process is considered to be an integral part of microangiopathy responsible for the major pathological complications, study of glycoprotein synthesis in the liver of diabetic animals is of considerable importance.

Liver perfusion of streptozotocin diabetic rats provides a suitable system for such investigations. Fortyeight hours after a single injection of the drug there is a decrease in insulin levels, with hyperglycaemia and hyperlipidaemia [6]. Reaven and Reaven [25] have shown that the ultrastructural appearance of the liver is well preserved in streptozotocin-treated rats after this time interval.

Protein synthesis by the liver is decreased in chronic diabetes induced in rats by partial pancreatectomy or alloxan injection [26, 27]. This has been confirmed in our experiments in acutely diabetic rats by the decrease in incorporation of ${ }^{3} \mathrm{H}$-leucine into secretory proteins. By contrast we observed that incorporation of ${ }^{14} \mathrm{C}$-glucosamine into secretory glycoproteins was not significantly reduced. Glucosamine was chosen as a marker for glycoprotein synthesis as it is not extensively catabolized and is largely incorporated into glycoproteins [4]. In hepatocytes the pattern of synthesis of secreted proteins was similar to that found in the liver perfusion studies. There was however no difference in the synthesis rate of non-secretory proteins (cellular) in hepatocytes from diabetic and control animals (Table 2).

The available leucine pool size of $80-90 \mu \mathrm{mol}$ compares with that of $72 \mu \mathrm{mol}$ found by Schreiber and Schreiber [21] in normal male Buffalo rats fed on a different diet. The glucosamine pool size was larger in diabetic animals. This is in contrast to the finding of Spiro [28] that the pools were similar in the plasma and liver in alloxan-diabetic and control rats. The method of calculation and the type of preparation were not analogous. The present results are not surprising and may even be predicted from Spiro's own hypothesis of alternative channelling of glucose in diabetes. Whichever is correct, the overall conclusion is unaltered. Incorporation of glucosamine into proteins was apparently unaffected by diabetes mellitus.

The amount of radioactive glucosamine incorporated into proteins depends not only on dilution by the glucosamine pool but also on the synthesis of glucosamine from intracellular glucose. On the one hand this might be expected to be higher in the diabetic animals because their plasma glucose levels are higher and its entry into hepatocytes is indepen- 
Table 3. Incorporation of ${ }^{3} \mathrm{H}$-leucine and ${ }^{14} \mathrm{C}$-glucosamine into different liver cell fractions after $3 \mathrm{~h}$ liver perfusion. Results given as cpm $\times$ $10^{-3} / \mathrm{mg}$ protein

\begin{tabular}{|c|c|c|c|c|c|c|}
\hline & \multicolumn{3}{|l|}{ Diabetic } & \multicolumn{3}{|c|}{ Non-diabetic } \\
\hline & ${ }^{3} \mathrm{H}$-leucine & $\begin{array}{l}{ }^{14} \mathrm{C}- \\
\text { glucosamine }\end{array}$ & $\begin{array}{l}\text { Ratio } \\
{ }^{3} \text { H-leucine }\end{array}$ & ${ }^{3} \mathrm{H}$-leucine & $\begin{array}{l}{ }^{14} \mathrm{C}- \\
\text { glucosamine }\end{array}$ & $\begin{array}{l}\text { Ratio } \\
{ }^{3} \mathrm{H} \text {-leucine }\end{array}$ \\
\hline & & & $\overline{{ }^{14} \mathrm{C}-\text { glucosamine }}$ & & & ${ }^{14} \mathrm{C}$-glucosamine \\
\hline Homogenate & $\begin{array}{c}35.3 \\
( \pm 6.5)\end{array}$ & $\begin{array}{c}3.1 \\
( \pm 0.5)\end{array}$ & 11.4 & $\begin{array}{c}43.0 \\
( \pm 11.8)\end{array}$ & $\begin{array}{r}3.4 \\
( \pm 0.6)\end{array}$ & 11.3 \\
\hline Golgi apparatus & $\begin{array}{c}64.4 \\
( \pm 10.9)\end{array}$ & $\begin{array}{c}27.7 \\
( \pm 4.3)\end{array}$ & 2.3 & $\begin{array}{c}63.5 \\
( \pm 5.7)\end{array}$ & $\begin{array}{c}19.0 \\
( \pm 4.5)\end{array}$ & 3.3 \\
\hline Mitochondria & $\begin{array}{c}54.3 \\
( \pm 11.5)\end{array}$ & $\begin{array}{c}14.4 \\
( \pm 3.5)\end{array}$ & 3.8 & $\begin{array}{c}29.0 \\
( \pm 7.9)\end{array}$ & $\begin{array}{c}5.3 \\
( \pm 1.6)\end{array}$ & 5.5 \\
\hline Rough membranes & $\begin{array}{c}85.5 \\
( \pm 6.2)\end{array}$ & $\begin{array}{c}23.3 \\
( \pm 3.3)\end{array}$ & 3.7 & $\begin{array}{c}87.5 \\
( \pm 8.7)\end{array}$ & $\begin{array}{c}12.9 \\
( \pm 1.8)\end{array}$ & 6.8 \\
\hline Smooth membranes & $\begin{array}{c}91.8 \\
( \pm 13.7)\end{array}$ & $\begin{array}{c}14.1 \\
( \pm 1.7)\end{array}$ & 6.5 & $\begin{array}{c}72.3 \\
( \pm 3.6)\end{array}$ & $\begin{array}{c}9.7 \\
( \pm 0.9)\end{array}$ & 7.5 \\
\hline Polysomes & $\begin{array}{c}40.7 \\
( \pm 5.0)\end{array}$ & $\begin{array}{c}4.9 \\
( \pm 0.9)\end{array}$ & 8.3 & $\begin{array}{r}40.9 \\
( \pm 13.2)\end{array}$ & $\begin{array}{c}3.3 \\
( \pm 1.1)\end{array}$ & 12.4 \\
\hline $\begin{array}{l}\text { Post-microsomal } \\
\text { supernatant }\end{array}$ & $\begin{array}{c}35.0 \\
( \pm 7.8)\end{array}$ & $\begin{array}{c}0.9 \\
( \pm 0.3)\end{array}$ & 37.6 & $\begin{array}{c}36.1 \\
( \pm 8.8)\end{array}$ & $\begin{array}{c}1.0 \\
( \pm 0.2)\end{array}$ & 36.1 \\
\hline
\end{tabular}

Each value represents mean \pm SEM of 3-6 experiments

dent of insulin action [29]. On the other hand, during a $2 \mathrm{~h}$ incubation the concentration of glycogen is probably the major regulator of intracellular glucose and this is higher in the normal animals [28]. The results in Figure 2 show no isotopic dilution of glucosamine by glucose. However, since the glucosamine pool sizes are increased then glycoprotein synthesis is evidently more accentuated than indicated by the uncorrected incorporation results (Figure 1B and the incorporation data given in the Tables).

The similar pattern of incorporation ratios in secreted proteins from liver perfusions and from hepatocytes, suggests that the pool size calculations are also representative of the situation in the perfused livers. There would thus be true differences in protein synthesis and glycosylation between nondiabetic and diabetic rats.

Since glycoproteins are both secreted and membrane bound, we measured the incorporation of ${ }^{3} \mathrm{H}$ leucine and ${ }^{14} \mathrm{C}$-glucosamine in the different cellular fractions. In the non-diabetic liver, glycoproteins are found in the various membrane organelles in which they undergo synthesis, secretion, or incorporation into structural proteins. There are no free glycoproteins in the cytosol [1]. In each membrane containing fraction from the diabetic livers there was more incorporation of glucosamine in relation to leucine (as shown by the lowered ${ }^{3} \mathrm{H}$-leucine: ${ }^{14} \mathrm{C}$-glucosamine ratio); but the distribution of glycoproteins among the different organelles was similar in the two groups of rats. This suggests that diabetes does not per se alter the pattern of normal glycoprotein synthesis, secretion, and incorporation into the various organelles (Table 3). Further, there appears to be increased glucosamine incorporation into the membrane and secreted proteins in the liver of diabetic rats by the normal pathway. These results may be in accord with Spiro's hypothesis of increased glycoprotein synthesis in diabetes [2], and provide experimental support for the clinical observation of increased levels of liver-derived plasma glycoproteins in diabetic subjects [30]. These proteins may produce alterations in the basement membranes of the kidney. Recently it has been shown in mice that multiple injections of glycosylated plasma proteins can cause pseudodiabetic renal glomerular changes [31].

In the diabetic rat there is thus an absolute decrease in protein synthesis but no change in the incorporation of glucosamine into glycoproteins. These findings may be explained in a number of ways. In the diabetic liver there may be no decrease in the synthesis of the protein backbone of the glycoproteins in comparison with the other proteins, and these proteins are glycosylated normally. Alternatively, if the decrease in protein synthesis extends to glycoproteins as well, it must be assumed that there is excessive glycosylation of glycoproteins. Another possible explanation is that there is an increase in total glycoprotein synthesis, perhaps involving gly- 
cosylation of protein not normally bearing carbohydrate residues.

Isolated perfused liver and hepatocytes preparations serve as useful models for the study of the metabolic events responsible for the increase in glycoprotein synthesis in diabetes. Agents which interfere with glycoprotein production can be studied in these systems to determine whether it may be possible to modify the development of diabetic microangiopathy.

Acknowledgement. This work was supported by a grant 604 from the United States-Israel Binational Science Foundation (BSF), Jerusalem, Israel, by a grant from the Joint Research Fund of the Hebrew University-Hadassah Medical School, and by a grant from Mr. M. Sirotkin, U.S. A. We thank Prof. R. N. Melmed for reviewing the manuscript and to Miss Daniella Landau for her skillful assistance.

\section{References}

1. Schachter H (1974) The subcellular sites of glycosylation. The metabolism and function of glycoproteins. Biochem Soc Symp 40: $57-51$

2. Spiro RG (1976) Search for a biochemical basis of diabetic microangiopathy. Diabetologia 12: 1-14

3. Spiro RG, Spiro MJ (1971) Effect of diabetes on the biosynthesis of the renal glomerular basement membrane. Diabetes 20: $641-648$

4. Robinson GB, Molnar J, Winzler R (1964) Biosynthesis of glycoproteins: I. Incorporation of glucosamine- ${ }^{14} \mathrm{C}$ into liver and plasma proteins of rat. J Biol Chem 239: 1134-1141

5. Richmond JE (1963) Studies on the metabolism of plasma glycoproteins. Biochemistry 2: 673-683

6. Bar-On H, Roheim PS, Eder HA (1976) Hyperlipoproteinemia in streptozotocin-treated rats. Diabetes 25: 509-515

7. Bar-On H, Roheim PS, Eder HA (1976) Serum lipoproteins and apolipoproteins in rats with streptozotocin-induced diabetes. J Clin Invest 57: 714-721

8. Mortimore GE, Woodside KH, Henry JE (1972) Compartmentation of free valine and its relation to protein turnover in perfused rat liver. J Biol Chem 247: 2776-2784

9. Bar-On H, Kook AI, Stein O, Stein Y (1973) Assembly and secretion of very low density lipoproteins by rat liver following inhibition of protein synthesis with cycloheximide. Biochim Biophys Acta 306: 106-114

10. Hamilton RL, Berry MN, Williams MC, Severinghous EM (1974) A simple and inexpensive membrane "lung" for small organ perfusion. J Lipid Res 15: 182-186

11. Morré DJ, Hamilton RL, Mollenhauer HH, Mahley RW, Cunningham WP, Cheetham RD, LeQuire VS (1970) Isolation of a Golgi apparatus-rich fraction from rat liver. J Cell Biol 44: 484-491

12. Hodson S, Brenchley G (1976) Similarities of Golgi apparatus membrane and plasma membrane in rat liver cells. J Cell Sci 20: $167-182$

13. Sottocasa GL, Kuylenstierna B, Ernstar L, Bergstrand A (1967) Separation and some enzymatic properties of the inner and outer membranes of rat liver mitochondria. Methods Enzymol 10: 448-463
14. Sunshine GH, Williams DJ, Rabin BR (1971) Role of steroid hormone in the interaction of ribosomes with the endoplasmic membranes of rat liver. Nature 230: 133-136

15. Dice JR, Schimke RT (1972) Turnover and exchange of ribosomal proteins from rat liver. J Biol Chem 247: 98-111

16. Mans RJ, Novelli GD (1960) A convenient, rapid and sensitive method for measuring the incorporation of radioactive amino acids into protein. Biochem Biophys Res Commun 3: 540-543

17. Zahlten RN, Stratman FW (1974) The isolation of hormonesensitive rat hepatocytes by a modified enzymatic technique. Arch Biochem Biophys 163: 600-608

18. Dawson RMC (1969) Physiological media, Krebs mammalian Ringer solutions. In: Dawson RNC, Elliott WH, Elliott DC, Jons KM (eds) Data for biochemical research. Oxford University Press, New York, p 507

19. Elliott KRF (1976) The effects of gelatin and bovine serum albumin on $\mathrm{Ca}^{2+}$ stimulation of gluconeogenesis in isolated rat hepatocytes. FEBS Lett 64: 62-64

20. de-Fernandez MTF, de Sesa ZM, Scornik OA (1970) Estimation of amino acids by isotopic dilution procedure using enzymatic synthesis of aminoacyl transfer ribonucleic acid. Biochemistry 9: 2280-2285

21. Schreiber G, Schreiber M (1972) Protein synthesis in single cell suspension from rat liver. J Biol Chem 247: 6340-6346

22. Whitehead JK, Dean HG (1968) The isotope derivative method in biochemical analysis. Methods Biochem Anal 16: $1-95$

23. Rubin IB, Goldstein G (1970) An ultrasensitive isotope dilution method for the determination of L-amino acids. Anal Biochem 33: 244-254

24. McMillan DE (1972) Elevation of glycoprotein fucose in diabetes mellitus. Diabetes 21: 863-871

25. Reaven EP, Reaven GM (1974) Mechanisms for development of diabetic hypertriglyceridemia in streptozotocin-treated rats. Effect of diet and duration of insulin deficiency. J Clin Invest 54: $1167-1178$

26. Penhos JC, Krahl ME (1963) Stimulus of leucine incorporation into perfused liver protein by insulin. Am J Physiol 204: $140-142$

27. Marsh JB (1961) Effect of fasting and alloxan diabetes on albumin synthesis by perfused rat liver. Am J Physiol 201: $55-57$

28. Spiro RG (1959) Role of insulin in two pathways of glucose metabolism: in vivo glucosamine and glycogen synthesis. Ann NY Acad Sci 82: 366-373

29. Cahill GF, Ashmore J, Earle AS, Zolta S (1958) Glucose penetration into liver. Am J Physiol 192: 491-496

30. McMillan DE (1970) Changes in serum proteins and proteinbound carbohydrates in diabetes mellitus. Diabetologia 6: 597-604

31. McVerry BA, Fisher C, Hopp A, Huehns ER (1980) Production of pseudodiabetic renal glomerular changes in mice after repeated injections of glucosylated proteins. Lancet I: 738-740

Received: February 15, 1980, and in revised form: July 16,1980

\section{Dr. E. M. Berry}

Lipid Research Laboratory

Department of Medicine B

Hadassah University Hospital

P.O.B. 12000

Jerusalem, Israel 